\title{
Efek Strategi Komunikasi Pemasaran Personal Selling PT Agricon Pada Petani Padi di Kabupaten Karawang
}

\section{Effect Marketing Communication Personal selling Strategy PT Agricon At Rice Farmers in Karawang}

\author{
Nindya Ayu Wradsari ${ }^{1}$, Anna Fatchiya ${ }^{2}$ \\ 12 Departemen Sains Komunikasi dan Pengembangan Masyarakat, \\ Fakultas Ekologi Manusia, Institut Pertanian Bogor, Bogor
}

\begin{abstract}
The objective of this research was to determine the personal selling of marketing communication strategy which was conducted by PT Agricon and to examine the factors related to the effects of it. This research applies simple random sampling which was conducted by using quantitative methods and supported by qualitative approach. The result showed that there were several activities which were implemented by the formulators of personal selling in the Village Rawagempol, such as demo plots, farmers meeting, field trip, and one day promo. Factors that are correlates positively to the tendency of farmer to buy the products are formulator communication skill in attracting farmer attention, the ability to explain the advantages of the product, the ability to use props well, farmer communication skill in being critical to formulator, and the ability of farmer to deliver attention and listen to the formulator. On farmer characteristics side, there were no factors that correlate to the tendency of farmers to buy the products.
\end{abstract}

Keywords: effect communication, marketing communication, personal selling

Abstrak

Tujuan dari penelitian ini adalah untuk menentukan personal selling strategi komunikasi pemasaran yang dilakukan oleh PT Agricon dan menguji faktor-faktor yang berhubungan dengan efek itu. Penelitian ini menggunakan simple random sampling yang dilakukan dengan menggunakan metode kuantitatif dan didukung oleh pendekatan kualitatif. Hasil penelitian menunjukkan bahwa ada beberapa kegiatan yang dilaksanakan oleh formulasi personal selling di Desa Rawa Gempol, seperti pertemuan petani plot demo, field trip, dan promo satu hari. Faktor-faktor yang berkorelasi positif dengan kecenderungan petani untuk membeli produk yang perumus keterampilan komunikasi dalam menarik perhatian petani, kemampuan untuk menjelaskan keuntungan dari produk, kemampuan untuk menggunakan alat peraga dengan baik, petani keterampilan komunikasi dalam bersikap kritis terhadap perumus, dan kemampuan petani untuk memberikan perhatian dan mendengarkan formulator. Di sisi petani karakteristik, tidak ada faktor-faktor yang berhubungan dengan kecenderungan petani untuk membeli produk.

Kata kunci: efek komunikasi, komunikasi pemasaran, personal selling

\section{Pendahuluan}

Pada kajian pemasaran dikenal istiah bauran pemasaran, terdiri atas product, price, place, dan juga promotion. Product berkaitan dengan costumer solution, price berkaitan dengan costumer cost, place berkaitan dengan convenience, sedangkan promotion berkaitan dengan communication. Sesuai dengan keempat pernyataan tersebut, hubungan antara pemasaran dan komunikasi sangat erat. Menurut Kusumastuti (2009) pelaku bisnis menganggap komunikasi adalah pemasaran dan pemasaran adalah komunikasi. Keduanya tidak dapat saling dipisahkan, sebab antara komunikasi dan pemasaran memegang peranan yang sangat penting bagi dunia bisnis. Tanpa komunikasi dalam pemasaran, konsumen tidak akan mengetahui keberadaan suatu produk.

Komunikasi pemasaran sebagai upaya untuk menjadikan seluruh kegiatan pemasaran dan promosi perusahaan dapat menghasilkan citra atau image yang bersifat konsisten bagi konsumen. Komunikasi pemasaran menuntut agar setiap pesan yang keluar harus berasal dari sumber yang sama sehingga segala informasi yang diumumkan perusahaan memiliki kesamaan tema serta positioning yang sama di mata konsumen (Morissan, 2010). Terdapat lima bentuk komunikasi pemasaran yang biasa disebut dengan bauran promosi, yaitu periklanan (advertising), promosi penjualan (sales promotion), hubungan masyarakat dan publisitas (public relation and 
publicity), pemasaran langsung (direct selling), dan penjualan tatap muka (personal selling). Kusumastuti (2009) juga mengemukakan personal selling atau penjualan tatap muka merupakan strategi komunikasi pemasaran yang paling efektif pada siklus terakhir dari proses pembelian.

Personal selling merupakan bentuk promosi secara face to face antara pemasar dengan konsumen mereka, sehingga strategi komunikasi pemasaran ini mempunyai kelebihan dibandingkan bentuk komunikasi pemasaran lainnya. Strategi komunikasi pemasaran personal selling sudah banyak diadopsi oleh beberapa perusahaan, salah satunya perusahaan pestisida PT Agricon. PT Agricon merupakan suatu perusahaan swasta nasional yang telah menyediakan pelayanan berupa produk pestisida. PT Agricon tidak bergerak sebagai distributor tetapi sebagai produsen pestisida. Sampai saat ini, PT Agricon telah melakukan pengembangan usaha, peningkatan kualitas produk, serta pelayanan bagi pelanggan. PT Agricon sebagai produsen pestisida, berkonsentrasi pada penyediaan sarana produk pertanian, mencakup mata rantai pertanian mulai dari pengolahan, hasil produksi, pendayagunaan hasil, distribusi, serta penyimpanan hasil pertanian.

Adanya persaingan dengan beberapa perusahaan pestisida yang lain, membuat PT Agricon semakin gencar dalam memasarkan produknya. Untuk itu strategi komunikasi pemasaran personal selling menjadi salah satu pilihan dalam memasarkan produknya kepada petani sebagai konsumen. Tujuan dari strategi komunikasi pemasaran ini ialah sebagai bentuk pembinaan kepada petani agar mengetahui produk PT Agricon dan mengetahui cara penggunaan yang tepat. Salah satu kendala yang biasanya dihadapi petani ialah tanaman atau lahan sawahnya terkena serangan hama, penyakit, dan juga gulma. Hal ini terkait dengan kebiasaan petani dalam menggunakan pestisida secara berlebihan yang akan menimbulkan dampak yang negatif bagi pengguna, dampak lingkungan, serta dampak sosial ekonomi. Oleh sebab itu, para petani sebaiknya menerapkan prinsipprinsip penggunaan pestisida, yaitu menggunakan secara legal, benar, dan bijaksana (Djojosumarto, 2008).

Pemasaran produk melalui personal selling membutuhkan sumber daya yang tidak sedikit. Menurut Risza (2010) kunci sukses suatu perusahaan tertumpu pada sumber daya manusia yang dimatangkan lewat pendidikan dan juga pelatihan, mulai dari tingkat paling dasar hingga manajemen tingkat tinggi. Petani saat ini menginginkan sesuatu yang serba instan, sehingga akhirnya membuat perusahaan pestisida perlu untuk melakukan demonstrasi melalui personal selling, sehingga para petani tidak hanya mengetahui dan menggunakan produk tetapi juga dapat menggunakan secara tepat.

Berdasarkan uraian tersebut, efek strategi komunikasi pemasaran personalsellingyang dilakukan oleh PT Agricon merupakan kajian penelitian yang menarik untuk diteliti karena berhubungan dengan proses komunikasi yang dilakukan PT Agricon kepada sasaran konsumennya yaitu petani melalui pemasaran produk, sehingga akan terlihat hubungan dari komunikasi pemasaran personal selling tersebut dikaji. Dengan demikian, tujuan penelitian ini adalah untuk: 1) mengidentifikasi strategi komunikasi pemasaran personal selling yang dilakukan oleh PT Agricon, 2) mengidentifikasi faktor-faktor yang ikut berhubungan dengan efek dari strategi komunikasi pemasaran personal selling yang dilakukan PT Agricon.

\section{Metode Penelitian}

Variabel independent yang digunakan dalam penelitian ini yaitu: karakteristik petani yang terdiri dari lusia, tingkat pendidikan, tingkat pendapatan, luas lahan, pengalaman usahatani, dan kemampuan komunikasi formulator yang terdiri dari menarik perhatian petani, dapat menjawab pertanyaan petani, memiliki kepercayaan diri dalam memperkenalkan produk, mampu menjelaskan produk, memberi contoh penggunaan produk, menjelaskan kelebihan produk, serta merekomendasikan untuk menggunakan produk, memberi tahu tempat penjualan, dapat menggunakan alat peraga dengan baik, dapat menyesuaikan waktu petani, sedangkan variabel dependent yang digunakan adalah kecenderungan petani membeli produk. Penelitian dilaksanakan di Desa Rawagempol, Kecamatan Cilamaya Wetan, Kabupaten Karawang pada bulan Februari 2013 sampai dengan Juli 2013. Jumlah responden berjumlah 35 orang, Penelitian menggunakan analisis statistik deskriptif dan uji statistik Rank Spearman.

\section{Hasil dan Pembahasan}

\section{Strategi Komunikasi Pemasaran Personal Selling PT Agricon}

Strategi personal sellingyang telah diterapkan 
Tabel 1 Distribusi Jawaban Responden tentang Kemampuan Komunikasi Formulator PT Agricon, di Desa Rawagempol, Tahun 2013

\begin{tabular}{|c|c|c|c|c|}
\hline No. & $\begin{array}{l}\text { Kemampuan komunikasi } \\
\text { formulator }\end{array}$ & $\begin{array}{l}\text { Rendah } \\
(\leq 88)(\%)\end{array}$ & $\begin{array}{c}\text { Sedang } \\
(88-96)(\%)\end{array}$ & $\begin{array}{c}\text { Tinggi } \\
(\geq 97)(\%)\end{array}$ \\
\hline 1. & Menarik perhatian petani & $7(20,0)$ & $14(40,0)$ & $14(40,0)$ \\
\hline 2. & Menjawab pertanyaan petani & $6(17,1)$ & $7(20,0)$ & $22(62,9)$ \\
\hline 3. & $\begin{array}{l}\text { Memiliki kepercayaan diri } \\
\text { dalam memperkenalkan produk }\end{array}$ & $4(11,4)$ & $8(22,9)$ & $23(65,7)$ \\
\hline 4. & $\begin{array}{l}\text { Mampu menjelaskan produk } \\
\text { dengan tepat }\end{array}$ & $12(34,3)$ & $6(17,1)$ & $17(48,6)$ \\
\hline 5. & Memberi contoh penggunaan & $4(11,4)$ & $7(20,0)$ & $24(68,6)$ \\
\hline 6. & Menjelaskan kelebihan produk & $2(5,7)$ & $10(28,6)$ & $23(65,7)$ \\
\hline 7. & $\begin{array}{l}\text { Merekomendasikan untuk } \\
\text { menggunakan produk }\end{array}$ & $3(8,6)$ & $13(37,1)$ & $19(54,3)$ \\
\hline 8. & Memberi tahu tempat penjualan & $7(20,0)$ & $16(45,7)$ & $12(34,3)$ \\
\hline 9. & $\begin{array}{l}\text { Menggunakan alat peraga } \\
\text { dengan baik }\end{array}$ & $7(20)$ & $13(37,1)$ & $15(42.9)$ \\
\hline 10. & Menyesuaikan waktu petani & $7(20)$ & $4(11,4)$ & $24(68,6)$ \\
\hline
\end{tabular}

formulator PT Agricon bertujuan untuk menyadarkan petani agar mengetahui keberadaan produk dan secara langsung merasakan manfaat dari produk tersebut, sehingga petani akan tertarik untuk membeli dan menggunakan produk. Selain itu melalui strategi personal selling diharapkan petani dapat menggunakan produk pestisida secara rasional sesuai dengan anjuran formulator dan petunjuk pemakaian yang tertera pada kemasan. Hal ini sesuai dengan teori-teori komunikasi pemasaran bahwa tujuan dari penjualan tatap muka atau personal selling yaitu dapat berkomunikasi dengankonsumen potensial secara langsung yang melibatkan pikiran dan emosi. Selain itu personal selling juga ikut membantu perusahaan dalam memperkenalkan produk baru atau memasukkan produk lama ke wilayah baru, sehingga memperoleh kesadaran produk dan konsumen potensial. Melalui personal selling dapat membuat hubungan interaktif secara dekat antara formulator dengan petani, sehingga dapat saling mengenal karakteristik petani secara lebih dalam dan dapat memberikan respon yang tepat (Kusumastuti, 2009).

Beberapakegiatan atau strategi yang dilakukan formulator dengan tujuan untuk mempromosikan produk PT Agricon kepada petani yaitu melalui demo plot, farmers meeting, field trip, dan one day promo. Demo plot merupakan kegiatan komunikasi dan promosi untuk menunjukkan kualitas produk PT Agricon melalui aplikasi secara langsung di lahan petani. Farmers meeting merupakan suatu bentuk kegiatan edukasi dan komunikasi produk PT Agricon kepada petani dengan cara mengumpulkan petani di suatu tempat, seperti kegiatan temu tani. Field trip merupakan kegiatan kunjungan ke lapangan dengan beberapa petani untuk melihat hasil demontrasi produk PT Agricon pada lahan petani yang telah dilakukan demo plot. One day promo merupakan kegiatan promosi dan edukasi dengan mengundang beberapa petani untuk datang ke kios pestisida, seperti kegiatan launching produk Maxima yang dihadiri oleh beberapa petani dari Desa Rawagempol di Desa Tegalsari, Kecamatan Cilamaya Wetan, Kabupaten Karawang.

Kegiatan-kegiatan seperti demo plot, farmers meeting, field trip, dan oneday promomemiliki kelebihan dan kekurangan. Peneliti melakukan penelitian dengan teknik pendekatan kualitatif pada kegiatan-kegiatan tersebut kepada formulator PT Agricon dan petani di Desa Rawagempol untuk melihat kegiatan atau strategi yang paling efektif dan yang paling tidak efektif dilihat dari beberapa aspek.

Masing-masing kegiatan memiliki kelebihan dan kekurangan yang berbeda-beda bergantung pada aspek yang ada. Kegiatan demo plot dapat dikatakan sebagai kegiatan yang paling efektif sebab, melalui kegiatan demo plot petani sadar adanya keberadaan produk PT Agricon, petani lebih leluasa untuk bertanya kepada formulator sehingga tidak 
Tabel 2 Distribusi Jawaban Responden tentang Kemampuan Komunikasi Petani, di Desa Rawagempol, Tahun 2013

\begin{tabular}{|c|c|c|c|c|}
\hline No. & Kemampuan komunikasi petani & $\begin{array}{c}\text { Rendah } \\
(\leq 55)(\%)\end{array}$ & $\begin{array}{c}\text { Sedang } \\
(56-62)(\%)\end{array}$ & $\begin{array}{c}\text { Tinggi } \\
(\geq 62)(\%)\end{array}$ \\
\hline 1. & Bersikap kritis kepada formulator & $8(22,9)$ & $15(42,9)$ & $12(34,3)$ \\
\hline 2. & $\begin{array}{l}\text { Memperhatikan dan mendengar } \\
\text { formulator }\end{array}$ & $9(25,7)$ & $13(37,1)$ & $13(37,1)$ \\
\hline 3. & $\begin{array}{l}\text { Paham cara menggunakan } \\
\text { produk dengan tepat }\end{array}$ & $10(28,6)$ & $17(48,6)$ & $8(22,9)$ \\
\hline
\end{tabular}

merasa canggung, memiliki kesempatan bertanya yang banyak kepada formulator, petani juga dapat berdiskusi dengan petani lain untuk bertukar pikiran, petani juga tahu cara menggunakan pestisida yang tepat melalui demo plot, dan petani termotivasi untuk menggunakan pestisida secara benar. Hampir seluruh aspek menyatakan bahwa demo plot merupakan kegiatan yang efektif dan hanya beberapa aspek yang menyatakan demo plot tidak efektif karena membutuhkan tenaga lebih banyak, biaya yang besar, dan waktu yang lebih banyak. One day promo merupakan kegiatan yang dinilai petani paling tidak efektif hampir seluruh aspek, walaupun kegiatan ini tidak membutuhkan waktu yang lama. Hal ini disebabkan hanya petani kunci yang mengikuti kegiatan tersebut. Selain itu petani merasa kegiatan one day promo hanya kegiatan launching produk yang kualitasnya belum tentu terjamin bagi petani. Petani di Desa Rawagempol lebih yakin terhadap suatu produk apabila telah melihat manfaat dan kualitas produk tersebut.

Berbeda dengan hasil penelitian yang dilakukan kepada petani, menurut formulator hampir seluruh kegiatan dapat dikatakan efektif, bergantung pada aspekaspeknya. Kegiatan demo plot paling efektif dilakukan ketika mendemonstrasikan produk baru, mereka juga merekomendasikan petani menggunakan produk, dan juga kemudahan dalam menyadarkan petani dari segi penyadaran pemakaian, kebutuhan, dan juga memotivasi untuk menggunakan secara benar, serta biaya yang tidak besar. Akan tetapi demo plot membutuhkan waktu yang paling lama dibandingkan kegiatan lainnya dan tidak efektifketikamendemonstrasikan produklama. Kegiatan farmers meeting dan field trip dapat dikatakan kegiatan yang paling efektif, walaupun terdapat beberapa aspek yang menyatakan tidak efektif jika dilakukan dalam kegiatan farmers meetingdan field trip. Kegiatan farmers meeting tidak efektifketika biaya yang dibutuhkan lebih besar, sama hal nya dengan field trip. Kegiatan field trip juga tidak efektif karena waktu yang dibutuhkan lebih banyak. Hanya beberapa aspek mewakili keefektivan kegiatan one day promo. Kegiatan tersebut hanya efektif dilakukan ketika mendemonstrasikan produk baru dan lama, merekomendasikan petani menggunakan produk, dan tidak membutuhkan waktu yang lama. Apabila dibandingkan dengan kegiatan yang lain, kegiatan one day promo termasuk ke dalam kegiatan paling tidak efektif.

Terdapat hasil perbandingan pada penelitian yang dilakukan kepada petani dan formulator. Petani mengatakan bahwa demo plot merupakan kegiatan yang paling efektif sebab melalui demo plot petani lebih menyadari dan memahami semua aspek yang ada, sedangkan menurut formulator demo plot cukup efektif di beberapa aspek, sebab tidak efektif jika produk lama yang didemonstrasikan dan membutuhkan waktu yang lebih banyak sehingga tenaga yang diperlukan akan lebih besar. Sebagian besarpetani merasa kegiatan demo plot lah yang dapat membuat petani lebih mengenal formulator dan produknya, walaupun sebagian kecil petani setuju bahwa demo plot membutuhkan waktu, biaya, dan tenaga yang lebih besar.

Formulator berpendapat kegiatan farmers meeting dan field trip yang paling efektif sebab formulator akan lebih mudah mempromosikan produk dengan cara mengumpulkan petani dalam satu tempat, serta melalui field trip petani akan langsung melihat hasil kerja dari produk Agricon. Berbeda dengan formulator, para petani berpendapat bahwa rangkaian dari kegiatan farmers meeting akan membuat petani kurang leluasa untuk bertanya kepada formulator, mengetahui cara menggunakan pestisida dengan tepat, serta berdiskusi dengan petani lain, sebab petani belum mengetahui hasil kerja dari produk Agricon. Responden tidak langsung percaya dengan produk hanya dari penjelasan formulator, 
Tabel 3 Distribusi Jawaban Responden tentang Kecenderungan Petani Membeli Produk, di Desa Rawagempol, Tahun 2013

\begin{tabular}{|c|c|c|c|c|}
\hline No. & Kemampuan komunikasi formulator & $\begin{array}{l}\text { Rendah } \\
(\leq 88)(\%)\end{array}$ & $\begin{array}{c}\text { Sedang } \\
(88-96)(\%)\end{array}$ & $\begin{array}{c}\text { Tinggi } \\
(\geq 97)(\%)\end{array}$ \\
\hline 1. & Menarik perhatian petani & $7(20,0)$ & $14(40,0)$ & $14(40,0)$ \\
\hline 2. & Menjawab pertanyaan petani & $6(17,1)$ & $7(20,0)$ & $22(62,9)$ \\
\hline 3. & $\begin{array}{l}\text { Memiliki kepercayaan diri dalam memperkenalkan } \\
\text { produk }\end{array}$ & $4(11,4)$ & $8(22,9)$ & $23(65,7)$ \\
\hline 4. & Mampu menjelaskan produk dengan tepat & $12(34,3)$ & $6(17,1)$ & $17(48,6)$ \\
\hline 5. & Memberi contoh penggunaan & $4(11,4)$ & $7(20,0)$ & $24(68,6)$ \\
\hline 6. & Menjelaskan kelebihan produk & $2(5,7)$ & $10(28,6)$ & $23(65,7)$ \\
\hline 7. & Merekomendasikan untuk menggunakan produk & $3(8,6)$ & $13(37,1)$ & $19(54,3)$ \\
\hline 8. & Memberi tahu tempat penjualan & $7(20)$ & $16(45,7)$ & $12(34,3)$ \\
\hline 9. & Menggunakan alat peraga dengan baik & $7(20)$ & $13(37,1)$ & $15(42,9)$ \\
\hline 10. & Menyesuaikan waktu petani & $7(20)$ & $4(11,4)$ & $24(68,6)$ \\
\hline
\end{tabular}

tetapi harus berupa kegiatan demonstrasi sekaligus penjelasan. Seperti kegiatan field trip, petani merasa cukup efektif karena petani secara langsung dapat melihat kualitas produk yang dipromosikan. Field trip dapat meningkatkan kecenderungan petani untuk membeli produk. Kegiatan tersebut cukup efektif bagi petani dan formulator, sebab petani dapat mengetahui keberadaan produk dan secara langsung melihat hasil demo plot, serta mengetahui cara penggunaan pestisida dengan tepat.

\section{Faktor-Faktor Yang Berhubungan dengan Efek Strategi Komunikasi Pemasaran Personal Selling}

\section{Karakteristik Responden}

\section{Usia Petani}

Petani yang menjadi responden dalam penelitian ini terbagi ke dalam tiga kategoriusia, yaitu rendah, sedang, dan tinggi. Penggolongan usia yang digunakan berdasarkan teori dari Havighurst dalam Mugniesyah (2006). Menurut teori dari Havighurst, responden pada kategori usia rendah termasuk ke dalam masa awal dari dewasa. Responden pada kategori usia sedang termasuk ke dalam masa usia pertengahan. Responden yang berada pada kategori usia tinggi termasuk ke dalam masa usia tua. Mayoritas usia responden berada pada kategori usia sedang atau masa usia pertengahan dengan proporsi yaitu 57,1\% (20 orang). Hal ini sesuai dengan nilai rataan yang diperoleh peneliti berdasarkan usia pada 35 orang petani yaitu 49 tahun. Responden dengan usia masa pertengahan atau kategori usia sedang memiliki proporsi jumlah dan persentase lebih banyak dibandingkan dengan responden pada kategeori usia tinggi atau masa usia tua. Tidak ada petani yang berusia pada kategori rendah atau masa awal dewasa. Ini berarti tidak ada responden yang berumur 18-29 tahun.

\section{Tingkat Pendidikan Petani}

Menurut data BPS (Badan Pusat Statistik), tingkat pendidikan digolongkan menjadi tiga kategori, yaitu rendah, sedang, dan tinggi. Mayoritas petani responden berpendidikan rendah atau tidak lulus/lulus SD dengan proporsi 42,8\% (15 orang). Ini artinya, sesuai dengan nilai rataan yang diperoleh peneliti bahwa rata-rata tingkat pendidikan petani responden berada pada kategori rendah. Responden yang memiliki pendidikan rendah lebih banyak disbanding dengan yang berpendidikan sedang (lulus SMP/sederajat) dan berpendidikan tinggi (lulus SMA/ sederajat/akademi/pergururan tinggi). Responden yang berpendidikan sedang dan tinggi memiliki proporsi yang sama yaitu $28,6 \%$ (10 orang).

\section{Tingkat Pendapatan Petani}

Tingkatpendapatanindividupetanimerupakan 
Tabel 4 Hubungan Nilai Koefisien Korelasi dan Nilai Signifikan Karakteristik Petani dengan Kecenderungan Petani Membeli Produk, di Desa Rawagempol, Tahun 2013

\begin{tabular}{|c|c|c|c|c|}
\hline No. & Kemampuan komunikasi petani & $\begin{array}{c}\text { Rendah } \\
(\leq 55)(\%)\end{array}$ & $\begin{array}{c}\text { Sedang } \\
(56-62)(\%) \\
\end{array}$ & $\begin{array}{c}\text { Tinggi } \\
(\geq 62)(\%)\end{array}$ \\
\hline 1. & Bersikap kritis kepada formulator & $8(22,9)$ & $15(42,9)$ & $12(34,3)$ \\
\hline 2. & Memperhatikan dan mendengar formulator & $9(25,7)$ & $13(37,1)$ & $13(37,1)$ \\
\hline 3. & $\begin{array}{l}\text { Paham cara menggunakan produk dengan } \\
\text { tepat. }\end{array}$ & $10(28,6)$ & $17(48,6)$ & $8(22,9)$ \\
\hline
\end{tabular}

Keterangan: *Berhubungan signifikan pada $\mathrm{p}<0,05$

pendapatan yang dikeluarkan oleh responden dalam sebulan. Pendapatan yang dikeluarkan oleh responden (individu) dalam sebulan berupa pengeluaran pangan dan nonpangan. Mayoritas petani responden di Desa Rawagempol, memiliki pengeluaran pada kategori rendah atau sebesar $<$ Rp 1.300.000 dengan proporsi 60\% (21 orang). Hal ini sesuai dengan nilai rataan sebesar $\mathrm{Rp} 1.200 .000$ bahwa pengeluaran responden dikategorikan rendah. Responden dengan pengeluaran tinggi $(\geq \operatorname{Rp} 2.150 .000)$ memiliki proporsi paling sedikit 8,6\% (3 orang). Responden dengan pengeluaran sedang $(\geq \mathrm{Rp} 1.300 .000-<\mathrm{Rp}$ 2.150.000) masih lebih banyak dibanding responden dengan pengeluaran tinggi. Menurut hasil wawancara, responden dengan pengeluaran sedang dan tinggi lebih banyak mengeluarkan kebutuhannya dalam hal kebutuhan non-pangan seperti bensin dan rokok.

\section{Luas Lahan Petani}

Luas lahan yang dimaksud dalam penelitian ini merupakan total luas lahan yang dimiliki petani sebagai responden untuk bertani. Berdasarkan hasil penelitian, mayoritas responden memiliki luas lahan sempit $(\leq 3-3,9 \mathrm{Ha})$ memiliki proporsi sebesar $57,1 \%$ (20 orang). Responden yang memiliki lahan yang luas ( $\geq 4$ ha) lebih sedikit dibanding responden dengan lahan sempit yaitu $42,9 \%$ (15 orang). Ini berarti sebagian besar petani memiliki luas lahan sempit. Hasil tersebut sesuai dengan nilai rata-rata luas lahan petani yang termasuk ke dalam kategori sempit yaitu $3,12 \mathrm{Ha}$.

\section{Pengalaman Usahatani}

Pengalaman usahatani yang telah dijalani petani sebagai responden beragam kurun waktunya. Pengalaman usahatani terbagi menjadi tiga kategori, yaitu rendah, sedang, dan tinggi. Hasil penelitian yang telah dilakukan peneliti menunjukkan bahwa mayoritas petani atau responden memiliki pengalaman usahatani yang tinggi ( $\geq 20$ tahun) dengan proporsi $51,4 \%$ (18 orang). Responden yang memiliki pengalaman usahatani yang rendah $(<10$ tahun) memiliki jumlah dan persentase jumlah paling sedikit dibandingkan responden yang memiliki pengalaman usahatani sedang $(\geq 10-<20$ ) dengan proporsi 11,4\% (4 orang). Jadi petani wilayah Desa Rawagempol memiliki pengalaman usahatani yang tinggi dalam kurun waktu $\geq 20$ tahun.

\section{Kemampuan Komunikasi Formulator}

Petugas lapang Agricon atau yang lebih dikenal dengan sebutan formulator diukur menurut kemampuan komunikasi formulator berdasarkan kemampuan dalam berbicara dan mendengarkan. Tingkat kemampuan komunikasi dari formulator dikategorikan menurut kategori rendah, sedang, dan tinggi. Kesepuluh indikator kemampuan komunikasi petani digabung, sehingga menghasilkan nilai total rata-rata. Mayoritas kemampuan komunikasi para formulator berada pada kategori tinggi dengan proporsi sebesar 40,0\% (14 orang). Formulator dengan kemampuan komunikasi kategori sedang memiliki proporsi $31,4 \%$ (11 orang), dan $28,6 \%$ (10 orang) formulator dengan kemampuan komunikasi rendah. Ini artinya sebagian besar formulator memiliki keterampilan komunikasi tinggi yang mampu mempengaruhi petani responden melalui pesan-pesan yang dikirimnya melalui saluran komunikasi atau channel tertentu yang digunakan. Menurut Berlo dalam Mugniesyah (2010) terdapat lima jenis keterampilan berkomunikasi terutama pada komunikasi verbal, diantaranya yaitu menulis, keterampilan berbicara, membaca, mendengarkan, dan berpikir. Keterampilan-keterampilan berkomunikasi ini lah yang dimiliki oleh formulator dan petani. Hasil jumlah dan persentase disajikan dalam Tabel 1. 
Tabel 5 Hubungan Nilai Koefisien Korelasi dan Nilai Signifikan Kemampuan Komunikasi Petani dengan Kecenderungan Petani Membeli Produk, di Desa Rawagempol, Tahun 2013

\begin{tabular}{lcc}
\hline \multicolumn{1}{c}{ Karakteristik petani } & \multicolumn{2}{c}{ Kecenderungan petani membeli produk } \\
& Koefisien Korelasi & Signifikan \\
\hline Usia & 0,068 & 0,698 \\
Tingkat pendidikan & 0,191 & 0,272 \\
Tingkat pendapatan & 0,278 & 0,106 \\
Luas lahan & 0,252 & 0,145 \\
Pengalaman usahatani & $-0,152$ & 0,384 \\
\hline
\end{tabular}

Keterangan: $* *$ Berhubungan signifikan pada $\mathrm{p}<0,01$

* Berhubungan signifikan pada $\mathrm{p}<0,05$

\section{Kemampuan Komunikasi Petani}

Kemampuan komunikasi petani diukur berdasarkan kemampuan komunikasi petani pada saat mendengarkan, memperhatikan, dan berbicara. Tingkat kemampuan komunikasi petani dikategorikan menurut kategori rendah, sedang, dan tinggi. Ketiga indikator kemampuan komunikasi petani yang digabung sehingga menghasilkan nilai total rata-rata, yaitu mayoritas berada pada kategori rendah dengan proporsi 42,9\% (15 orang), pada kategori tinggi yaitu sebesar $31,4 \%$ (11 orang), dan pada kategori sedang sebesar $25,7 \%$ (9 orang). Jadi, dapat dikatakan kemampuan komunikasi yang dimiliki oleh para petani sebagai responden dikategorikan rendah. Penyebabnya yaitu terdapat faktor-faktor yang berhubungan dengan ketepatan dari para petani dalam berkomunikasi, diantaranya keterampilan berkomunikasi, sikap, tingkat pengetahuan, dan sistem sosial budaya yang dijabarkan sebagai berikut.

\section{Kencederungan Petani Membeli Produk}

Dari data pada Tabel 3 informasi tentang kecenderungan dari petani membeli produk. Kecenderungan para petani dalam membeli produk menurut teori perilaku konsumen akan melalui beberapa tahapan sebelum petani memutuskan untuk membeli produk, diantaranya petani butuh terhadap produk, petani tertarik untuk membeli produk, petani akan mencari informasi kepada petani lain atau suatu kios terhadap produk yang dibutuhkan dan ingin dibeli, selanjutnya petani akan cenderung lebiih membandingkan produk yang ingin dibeli dengan produk perusahaan lain (Kotler dan Amstrong, 2008).
Tingkat kecenderungan dari petani membeli produk dikategorikan menurut kategori rendah, sedang, dan juga tinggi. Berdasarkan hasil wawancara pada 35 responden, kecenderungan petani membeli produk Agricon berada pada kategori rendah dengan proporsi $45,7 \%$ (16 orang). Pada kategori tinggi memiliki proporsi sebesar $17,1 \%$ (6 orang) yang lebih sedikit dibandingkan kategori sedang dengan proporsi yaitu 37,1\% (13 orang). Petani responden berada pada kategori rendah dikarenakan tidak semua petani mengalami tahapan-tahapan sebelum membeli produk Agricon, walaupun pada akhirnya hampir semua responden memutuskan untuk membeli produk Agricon.

Kebutuhan para petani pada produk Agricon termasuk ke dalam kategori tinggi dengan proporsi $45.7 \%$ (16 orang). Tiga tahapan selanjutnya, yaitu ketertarikan untuk membeli produk Agricon dan mencari informasi tentang produk Agricon berada pada kategori sedang. Akan tetapi pada tahap terakhir yaitu membandingkan produk Agricon dengan produk lain berada pada kategori sedang, proporsi pada kategori tinggi lebih sedikit dibandingkan kategori rendah. Sama halnya dengan ketertarikan untuk membeli produk Agricon jumlah persentase pada kategori rendah lebih banyak dibandingkan pada kategori tinggi.

Hampir semua responden berada pada kategori sedang dalam membutuhkan produk PT Agricon, tertarik untuk membeli produk PT Agricon, mencari informasi tentang produk PT Agricon yang akan dibeli, dan membandingkan produk PT Agricon yang akan dibeli dengan produk perusahaan lain. Petani responden merasa atau menyadari membutuhkan produk PT Agricon dengan adanya rangsangan eksternal dari formulator pada saat memperkenalkan produk. 
Selanjutnya pada saat responden membutuhkan produk, maka kemudian akan timbul minat untuk mencari informasi yang lebih banyak dan lebih mendalam mengenai produk yang mereka butuhkan agar dapat menentukan pilihan dengan tepat. Informasi biasanya didapatkan dari petani lain, terutama yang memiliki pengalaman usahatani tinggi. Selain itu informasi bisa juga didapatkan dari penjual kios dan formulator yang ada di wilayahnya.

\section{Analisis Hubungan Karakteristik Petani dengan Kecenderungan Petani Membeli Produk}

Hasil uji korelasi pada Tabel 4 menunjukkan nilai signifikan 0,698 lebih besar dari $\alpha(0,05)$, sehingga dapat dikatakan usia ternyata tidak berhubungan dengan kecenderungan petani membeli produk. Hal ini dapat terjadi karena mayoritas usia responden berada pada masa usia tua dan dewasa pertengahan. Selain itu pengalaman usahatani responden berada pada kategori sedang ( $\geq 10-<20$ tahun) dan tinggi ( $\geq 20$ tahun). Oleh karena itu, responden sudah mengetahui produk apa yang telah biasa digunakan dan merasa tidak perlu lagi membandingkan atau mencari informasi mengenai produk baru.

Tingkat pendidikan menunjukkan nilai signifikan sebesar 0,272 yang artinya lebih besar dari $\alpha(0,05)$. Ini menunjukkan tidak terdapat hubungan yang signifikan antara pendidikan dengan kecenderungan para petani membeli produk, dikarenakan pendidikan bukan merupakan faktor yang penting dalam mencari informasi mengenai suatu produk pestisida, sehingga responden cenderung mencari informasi mengenai produk pestisida dari petani lain atau formulator.

Tingkat pendapatan petani yang dikeluarkan petani tidak memiliki hubungan yang signifikan dengan kecenderungan para petani membeli produk, sebab nilai signifikan menunjukan lebih besar dari nilai $\alpha(0,05)$ yaitu sebesar 0,106 . Tingkat pendapatan yang dikeluarkan petani merupakan pengeluaran petani sebagai individu yang rata-rata pengeluarannya untuk kebutuhan pangan dan nonpangan. Pendapatan yang dikeluarkan petani untuk membeli pestisida perhitungannya akan berbeda dengan tingkat pendapatan yang dikeluarkan untuk kebutuhan seharihari. Selain itu mayoritas petani memiliki tingkat pendapatan yang dikeluarkan pada kategori rendah. Hal inilah yang menjadi penyebab tingkat pendapatan yang dikeluarkan tidak memiliki hubungan yang signifikan dengan kecenderungan petani membeli produk.

Luas lahan tidakberhubungansecarasignifikan dengan kecenderungan petani membeli produk, sebab nilai signifikan lebih besar dari $\alpha(0,05)$ yaitu sebesar 0,145 . Hal ini dapat terjadi karena walaupun mayoritas petani memiliki luasan lahan yang sempit, responden tetap memerlukan pestisida sebagai dasar kebutuhan mereka. Pestisida diperlukan petani ketika mereka mempunyai luas lahan sawah yang berbedabeda. Pestisida telah menjadi kebutuhan dasar petani karena petani memerlukan pestisida untuk mengobati lahan sawahnya yang terkena serangan hama dan penyakit. Oleh karena itu, setiap petani yang memiliki lahan sawah akan selalu membutuhkan pestisida, sehingga pasti membeli pestisida.

Pengalaman usahatani menunjukkan tidak terdapat hubungan yang signifikan antara pengalaman usahatani dengan kecenderungan petani membeli produk, sebab nilai signifikan 0,384 lebih besar dari $\alpha$ $(0,05)$. Mayoritas pengalaman petani yang sedang atau $\geq 10<20$ tahun dan tinggi atau $\geq 20$ tahun membuat responden tidak perlu membandingkan produk yang telah biasa mereka gunakan. Sebagian besar petani membutuhkan produk, tertarik membeli produk, dan mencari informasi mengenai produk, namun hanya sebagian kecil yaitu hanya $20 \%$ ( 7 orang) yang membandingkan produk yang biasa mereka gunakan dengan produk perusahaan lain. Nilai korelasi pengalaman usahatani negatif yang artinya semakin tinggi pengalaman usahatani maka justru akan semakin rendah kecenderungan petani membeli produk.

\section{Analisis Hubungan Kemampuan Komunikasi Formulator dengan Kecenderungan Petani Membeli Produk}

Kemampuan komunikasi formulator dalam menarik perhatian petani memiliki hubungan yang signifikan dengan tingkat kecenderungan petani membeli produk. Nilai signifikan sebesar 0,021 yang berarti lebih kecil dari nilai $\alpha(0,05)$. Kemampuan berbahasa yang sopan dan juga dapat menggunakan bahasa yang digunakan petani sehari-hari, membuat responden paham pada bahasa yang digunakan formulator. Oleh sebab itu mayoritas responden memiliki kecenderungan untuk membeli produk sebab kemampuan komunikasi formulator dalam 
menarik perhatian petani yang tinggi sebesar 40\% (14 orang). Nilai korelasi sebesar 0,387 artinya hubungan antara dua variabel tidak erat.

Kemampuan komunikasi formulator dalam menjelaskan kelebihan produk memiliki hubungan yang signifikan dengan kecenderungan petani membeli produk. Nilai signifikan menunjukkan lebih kecil dari $\alpha(0,05)$ sebesar 0,015 . Nilai korelasi sebesar 0,407 menunjukkan hubungan yang cukup erat antara dua variabel. Hal ini disebabkan oleh pada saat formulator tengah mempromosikan produknya, formulator menjelaskan keunggulan produk PT Agricon dengan baik dan mampu membandingkan produk PT Agricon dengan produk perusahaan lain. Petani sebagai konsumen merasa yakin bahwa produk PT Agricon memang memiliki keunggulan dibandingkan dengan produkperusahaan pestisidalainnya. Apabila responden mengetahui keunggulan produk dengan baik maka kecenderungan petani untuk membeli produk akan semakin tinggi. Formulator yang memperkenalkan keunggulan produk akan berpengaruh terhadap kecenderungan petani membeli produk, terutama pada saat formulator memperkenalkan produk insektisida merek Spontan.

Kemampuan komunikasi formulator diukur dari penggunaan alat peraga pada saat mempromosikan produk, berupa flip chart, brosur, poster, video, dan slide. Selain itu juga diukur apakah formulator selalu menggunakan salah satu alat peraga tersebut pada saat mempromosikan produk. Hasil korelasi terlihat bahwa kemampuan komunikasi dari para formulator dalam menggunakan alat peraga pada saat promosi produk memiliki hubungan yang signifikan dengan kecenderungan petani membeli produk. Hubungan yang signifikan ini memiliki nilai lebih kecil dari $\alpha(0,05)$ yaitu sebesar 0,033. Adanya hubungan antara kemampuan komunikasi formulator dalam menggunakan alat peraga dengan kecenderungan petani membeli produk disebabkan pada saat formulator menjelaskan suatu produk atau ketika memperkenalkan produk baru PT Agricon kepada responden atau petani, mereka selalu menggunakan kertas flip chart dan membagikan brosur gratis kepada petani. Tujuannya adalah agar petani mendapatkan informasi mengenai produk tidak hanya dari penjelasan formulator, tetapi petani juga bisa mendapatkan informasi mengenai produk dari apa yang tertera pada brosur.

Formulator menjelaskan secara mendalam mengenai produknya, namun secara singkat penjelasan produk dapat petani lihat di brosur yang dibagikan. Penggunaan video, poster, dan slidejuga memudahkan petani untuk memahami apa yang formulator sampaikan. Oleh sebab itu, kecenderungan petani untuk membeli produk akan semakin tinggi ketika alat peraga yang digunakan oleh formulator memudahkan petani untuk memahami apa yang dijelaskan formulator. Selain itu dapat ditunjukkan dengan bahwa tidak ada formulator yang berada pada kategori rendah dalam menggunakan alat peraga. Nilai korelasi sebesar -0,362 menunjukkan hubungan yang tidak erat. Hubungan korelasi yang negatif menjabarkan bahwa semakin tinggi kemampuan formulator dalam menggunakan alat peraga dengan baik maka semakin rendah kecenderungan petani membeli produk.

\section{Analisis Hubungan Kemampuan Komunikasi Petani dengan Kecenderungan Petani Membeli Produk}

Kemampuan komunikasi petani dalam bersikap kritis kepada formulator memiliki hubungan yang signifikan dengan kecenderungan petani membeli produk. Nilai signifikan sebesar 0,003 lebih kecil dari $\alpha(0,01)$. Kedua variabel tersebut dapat berhubungan sebab mayoritas petani sebagai responden selalu bertanya kepada formulator tentang manfaat produk dan berani membandingkan produk PT Agricon dengan produk perusahaan lain. Selain itu petani juga aktif bertanya mengenai harga produk dan berani untuk mengemukakan pendapatnya pada saat formulator sedang mempromosikan produknya. Sikap kritis petani muncul karena sebagian besar memiliki usia dan pengalaman usahatani yang sedang dan tinggi. Hal ini yang membuat petani sebagai responden memiliki kecenderungan untuk membeli produk sehingga berhubungan dengan sikap kritis yang dimiliki responden. Nilai koefisien korelasi sebesar 0.485 menunjukkan bahwa hubungan antara dua variabel cukup erat.

Nilai signifikan sebesar 0,024 yang menjabarkan kemampuan komunikasi petani dalam memperhatikan dan mendengarkan formulator lebih kecil dari $\alpha$ $(0,05)$. Nilai koefisien korelasi yakni sebesar 0,380 menunjukkan bahwa hubungan antara dua variabel tidak erat. Ini menunjukkan bahwa terdapat hubungan yang signifikan antara kemampuan komunikasi petani dalam memperhatikan dan juga mendengarkan formulator dengan kecenderungan petani membeli produk. Pada 
saat formulator menjelaskan produk, kemampuan petani dalam memperhatikan dan mendengarkan ternyata dapat juga membuat responden cenderung ingin membeli produk. Ketika formulator mempromosikan suatu produk, responden akan memperhatikan kemudian mendengarkan bagaimana cara formulator berkomunikasi. Mayoritas dari responden memahami bahasa dan mengerti apa yang diucapkan formulator. Selain itu mayoritas petani telah mengetahui lokasi kios yang menjual produk PT Agricon, hal ini yang membuat kecenderungan petani untuk membeli produk PT Agricon menjadi tinggi sebab melalui kemampuan memperhatikan dan mendengarkan, petani menjadi tertarik untuk mencari informasi kemudian akan membandingkan produk PT Agricon dengan produk perusahaan lain.

\section{Kesimpulan}

Kesimpulan penelitian ini yaitu strategi personal selling di desa target pemasaran, berupa demo plot, farmers meeting, field trip, dan one day promo. Kemampuan komunikasi dari formulator dan petani terbukti dapat ikut meningkatkan kecenderungan dari petani untuk membeli produk. Beberapa kemampuan formulator tersebut, berupa menarik perhatian petani, menjelaskan kelebihan dari produk, dan menggunakan alat peraga dengan baik, sedangkan kemampuan para petani, berupa bersikap kritis kepada para formulator dan memperhatikan dan juga mendengarkan formulator. Mayoritas dari responden memahami bahasa dan mengerti apa yang diucapkan formulator. Selain itu mayoritas petani telah mengetahui lokasi kios yang menjual produk PT Agricon, hal ini yang membuat kecenderungan petani untuk membeli produk PT Agricon menjadi lebih tinggi.

\section{Daftar pustaka}

Cangara H. 2006. Pengantar Ilmu Komunikasi. Jakarta (ID): PT Raja Grafindo Persada.

Damirhatini RS, Jati A. 2006 (September). Hubungan Karakteristik Petani dengan Kompetensi Agribisnis Pada Usahatani Sayuran di Kabupaten Kediri Jawa Timur. Jurnal Penyuluhan. [Internet]. [dikutip tanggal 2 Maret 2013]. 1(1): 41-48.

Djojosumarto P. 2008. Pestisida dan Aplikasinya. Jakarta (ID): Agro Media Pustaka.

Djojosumarto P. 2008. Teknik Aplikasi Pestisida Pertanian. Yogyakarta (ID): Kanisius.

Kotler P, Amstrong G. 2008. Prinsip-prinsip Pemasaran. Ed ke-12. Jakarta (ID): Erlangga.

Kusumastuti YI. 2009. Bab 12 Komunikasi Pemasaran. Sardin DS, editor. Komunikasi Bisnis. Bogor (ID): IPB Press.

Morissan MA. 2010. Periklanan: Komunikasi Pemasaran Terpadu. Jakarta (ID): Kencana.

Hubies AVS, Amanah S, Djuara PL, Ninuk P, Yatri K, Mugniesyah SS . 2010. Bab 3 Model-model Komunikasi., editor. Dasar-dasar komunikasi. Bogor (ID): IPB Press.

Risza S. 2010. Masa Depan Perkebunan Kelapa Sawit Indonesia. Yogyakarta (ID): Kanisius.

Shimp T. 2003. Periklanan Promosi Aspek Tambahan Komunikasi Terpadu. Nurcahyo, editor. Ed ke5. Jakarta (ID): Erlangga.

Simandjuntak, Joh P, et al. 2003. Public Relations. Yogyakarta (ID): Graha Ilmu.

Singarimbun M, Effendi S. 1989. Metode Penelitian Survai. Jakarta (ID): LP3ES.

Suyanto M. 2007. Marketing Strategy Top Brand Indonesia. Yogyakarta (ID): Andi. 